\title{
Hereditary Renal Amyloidosis with a Novel Variant Fibrinogen
}

\author{
Tomoyuki Uemichi, Juris J. Liepnieks, and Merrill D. Benson \\ Departments of Medicine and Medical Genetics, Indiana University, and Veterans Affairs Medical Center, Indianapolis, Indiana 46202
}

\begin{abstract}
Two families with hereditary renal amyloidosis were found to have a novel mutation in the fibrinogen $A \alpha$ chain gene. This form of amyloidosis is an autosomal dominant condition characterized by proteinuria, hypertension, and subsequent azotemia.

DNAs of patients with amyloidosis were screened for a polymorphism in fibrinogen $\mathrm{A} \alpha$ chain gene by single-strand conformation polymorphism analysis, and affected individuals from two kindreds were found to have a mutation. Both of these kindreds are American of Irish descent presenting with nonneuropathic, nephropathic amyloidosis in the fifth to the seventh decade of life. DNA sequencing showed a point mutation in the fibrinogen $\mathrm{A} \alpha$ chain gene that is responsible for substitution of valine for glutamic acid at position 526. By restriction fragment length polymorphism analysis, 7 affected individuals and 14 asymptomatic individuals in these two kindreds were positive for the fibrinogen $A \alpha$ chain Val 526 gene. Fibrinogen was isolated from plasma of a heterozygous gene carrier and shown to contain $\sim \mathbf{5 0} \%$ variant fibrinogen.

Discovery of this new mutation confirms the association between fibrinogen $A \alpha$ chain variant and hereditary renal amyloidosis and establishes a new biochemical subtype of amyloidosis. (J. Clin. Invest. 1994. 93:731-736.) Key words: amyloidosis • fibrinogen • nephropathy $\bullet$ kidney $\bullet$ hereditary
\end{abstract}

\section{Introduction}

Hereditary amyloidosis is a heterogeneous syndrome characterized as a late-onset autosomal dominant disorder with amyloid deposition in various tissues. It was originally classified by clinical presentation, but progress in biochemistry has made it possible to classify it by amyloid precursor protein (1). Several kinds of hereditary amyloidosis are known to be caused by single amino acid substitutions in precursor proteins: familial amyloid polyneuropathy (transthyretin, apolipoprotein $\mathrm{Al}$, and gelsolin), familial Alzheimer's disease (amyloid precursor protein), and hereditary cerebral hemorrhage with amyloidosis (amyloid precursor protein and cystatin C) (2-12). Hereditary renal amyloidosis (HRA) ${ }^{1}$ is a relatively rare subtype of hereditary systemic amyloidosis, where the principal organ involvement is renal. Since Ostertag described HRA in 1932 (13),

Address correspondence and reprint requests to Dr. Merrill D. Benson, Veterans Affairs Medical Center, 1481 W. 10th St., Room A-772, Indianapolis, IN 46202.

Received for publication 2 August 1993 and in revised form 18 October 1993.

1. Abbreviations used in this paper: HRA, hereditary renal amyloidosis; SSCP, single-strand conformation polymorphism.

The Journal of Clinical Investigation, Inc.

Volume 93, February 1994, 731-736 several kindreds have been reported. Although it was the first reported hereditary amyloidosis, the protein responsible for its amyloid deposit in most cases has remained unknown. In a previous study, we found a partial amino acid sequence of fibrinogen $\mathrm{A} \alpha$ chain with an amino acid substitution in deposited amyloid in a patient with HRA and proposed a variant fibrinogen A $\alpha$ chain as a possible cause of HRA (14).

In this paper, we report about two unrelated kindreds with HRA who share a novel mutant fibrinogen $\mathrm{A} \alpha$ chain gene.

\section{Cases}

The family pedigrees are shown in Fig. 1. Both families are of Irish descent with all members presently living in the United States. Ancestors of these two kindreds immigrated to the United States in the 18th to mid-19th century independently. Exclusive genealogic study revealed no evidence of linkage between these two kindreds.

Family D. The propositus (III-11) is a 53-yr-old man who, at the age of 43 , was noted on a yearly physical examination to have proteinuria, which increased during the next $3 \mathrm{yr}$ to the nephrotic range. Amyloidosis was diagnosed by renal biopsy. A liver biopsy at age 51 revealed amyloid in blood vessel walls only. He has not had any cardiac or neurological symptoms.

Propositus' father (II-2) died at age 69 of renal failure. An autopsy showed amyloid in the kidneys (Fig. 2) and spleen, but not in the liver or heart. Each kidney weighed $90 \mathrm{~g}$ and the spleen weighed $250 \mathrm{~g}$. He had paedal edema, but no signs of neuropathy.

This propositus' uncle (II-6) noted the onset of severe, generalized pruritus at age $59 \mathrm{yr}$ and was found to have proteinuria, anemia, and hypertension. Renal dysfunction and pancytopenia gradually progressed and he died at age 61 .

A cousin of the propositus (III-1) was first found during an annual examination at age $61 \mathrm{yr}$ to have proteinuria. Renal biopsy showed amyloid deposition. Renal dysfunction rapidly progressed in a year, and he is now on hemodialysis.

A 54-year-old brother of the propositus (III-10) was noted to have proteinuria, but no biopsy has been performed yet.

Family $R$. A 62-yr-old woman (II-3) who had been under care with a diagnosis of small cell carcinoma of lung was noted to have decreased kidney function at age 60 . Kidney biopsy showed amyloid deposition. An echocardiogram showed left ventricular hypertrophy and thickening of the mitral valve.

The propositus' 70-yr-old brother (II-1), who had a longstanding history of essential hypertension, was noted to have proteinuria at the age of 66 . The diagnosis of amyloidosis was made by kidney biopsy. A right heart myocardial biopsy demonstrated no evidence of cardiac amyloid, although an echocardiogram showed concentric left ventricular hypertrophy and a sparkling appearance suggestive of cardiac amyloid together with heavily calcified aortic valve. He has been on continuous ambulatory peritoneal dialysis since he was $68 \mathrm{yr}$ old.

Their father died at age 53 of bronchial cancer and paternal grandfather died in his fifties of kidney disease. Their mother died at age 98 . 


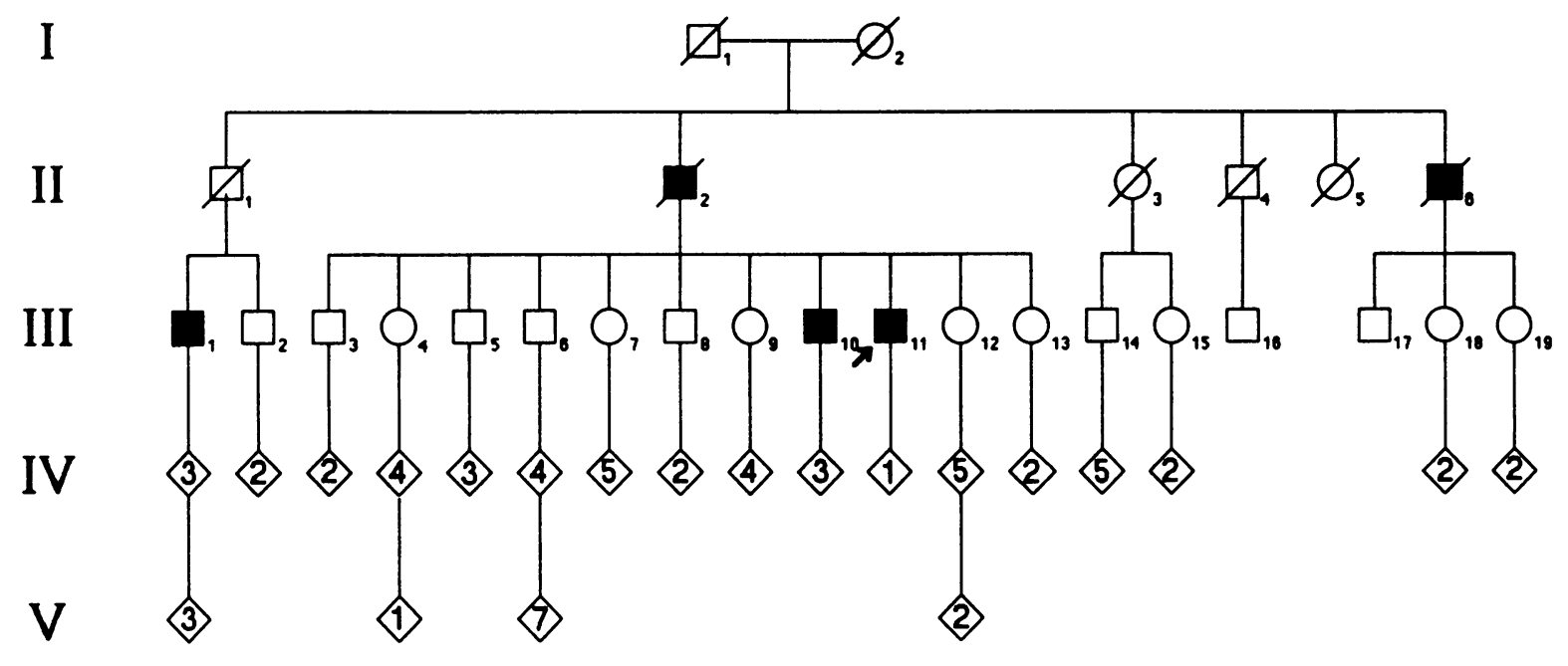

Family D

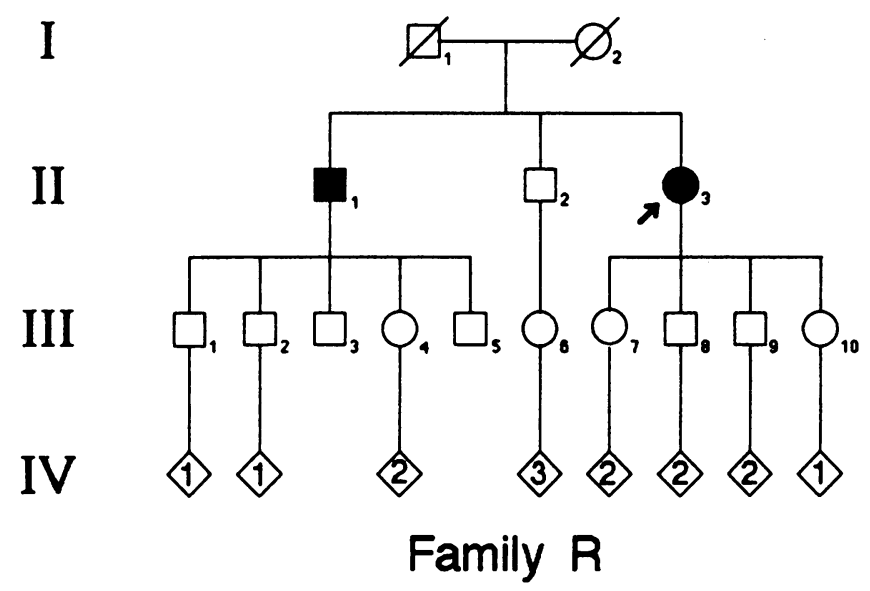

Figure 1. Pedigrees of family D and family R. Solid symbols, individuals with amyloidosis; arrows, propositus; diamonds, multiple sibs.

\section{Methods}

Reagents. GeneAmp PCR reagents were obtained from Perkin-Elmer Cetus Corp. (Norwalk, CT). MDE gel solution was from AT Biochem (Malvern, PA). Centricon-30 microconcentrator was from Amicon (Beverly, MA). Sequenase Version 2.0 was from U.S. Biochemical Corp. (Cleveland, $\mathrm{OH}$ ). MaellI was from Boehringer Mannheim Biochemicals (Indianapolis, IN). Lysine Sepharose 4B, gelatin Sepharose 4B and Sephadex G-50 superfine were supplied by Pharmacia (Uppsala, Sweden ). Ultrasphere-ODS was from Beckman Instruments, Inc. (Fullerton, CA).

DNA isolation. Total genomic DNA was isolated from peripheral blood cells of five affected individuals (family D: III-1, III-10, and III-1 1, family R: II- 1 and II-3), 22 individuals at risk ( 10 from family D and 12 from family R) (15). DNAs of II-1, II-2, and II-6 of family D were obtained from autopsied materials.

Single-strand conformation polymorphism (SSCP) analysis. Fibrinogen gene of three affected members of these kindreds (family D: III-1 1; family R: II-1 and II-3) were examined by SSCP analysis. SSCP was performed according to the method of Orita et al. with some modifications as described previously $(16,17)$. Oligonucleotide primers
(Fib3 primer 5'-CTTCGACACTGCCTCAACTG-3' and Fib2 primer 5 '-TCCTCTGTTGTAACTCGTGCT-3') were synthesized to amplify a part of exon 5 of fibrinogen $A \alpha$ chain gene (nucleotides 4832-5051), which codes the carboxyl-terminal region of $\mathrm{A} \alpha$ chain found in a previous study $(18,14)$. PCR was performed using primers, GeneAmp PCR reagents, $60 \mu \mathrm{M}$ dNTPs, and $30 \mathrm{nM}^{32} \mathrm{P}$-labeled dCTP (final concentration). PCR conditions were 30 cycles of denaturing at $94^{\circ} \mathrm{C}$ for $30 \mathrm{~s}$, annealing at $62^{\circ} \mathrm{C}$ for $30 \mathrm{~s}$, and extension at $72^{\circ} \mathrm{C}$ for $1 \mathrm{~min}$. PCR products were diluted with 100 vol of buffer containing $50 \%$ formamide, $0.05 \%$ SDS, $0.02 \%$ xylene cyanol FF, $0.02 \%$ bromophenol blue, and $10 \mathrm{mM}$ EDTA, heated at $95^{\circ} \mathrm{C}$ for $5 \mathrm{~min}$ and loaded onto a $0.5 \times$ MDE gel $(40 \times 20 \times 0.04 \mathrm{~cm})$. The gel was electrophoresed at $4^{\circ} \mathrm{C}$ for $16 \mathrm{~h}$ at $8 \mathrm{~W}$, dried, and exposed to Kodak X-Omat film.

Direct DNA sequence analysis. DNA was examined by the direct DNA sequence method described previously (19). $10 \mu$ l of symmetric PCR product was electrophoresed through $4 \%$ Nusieve GTG agarose gel. The band of $220 \mathrm{bp}$ was cut out and melted in $300 \mu \mathrm{l}$ of Tris-EDTA buffer. Asymmetric PCR was performed in $100 \mu \mathrm{l}$ reaction using $10 \mathrm{ng}$ of Fib3 primer, $300 \mathrm{ng}$ of $\mathrm{Flb} 2$ primer, and $1 \mu \mathrm{l}$ of agarose extracted sample in the same condition described above. Sample was extracted with chloroform and subjected to spin dialysis with a Centricon-30 


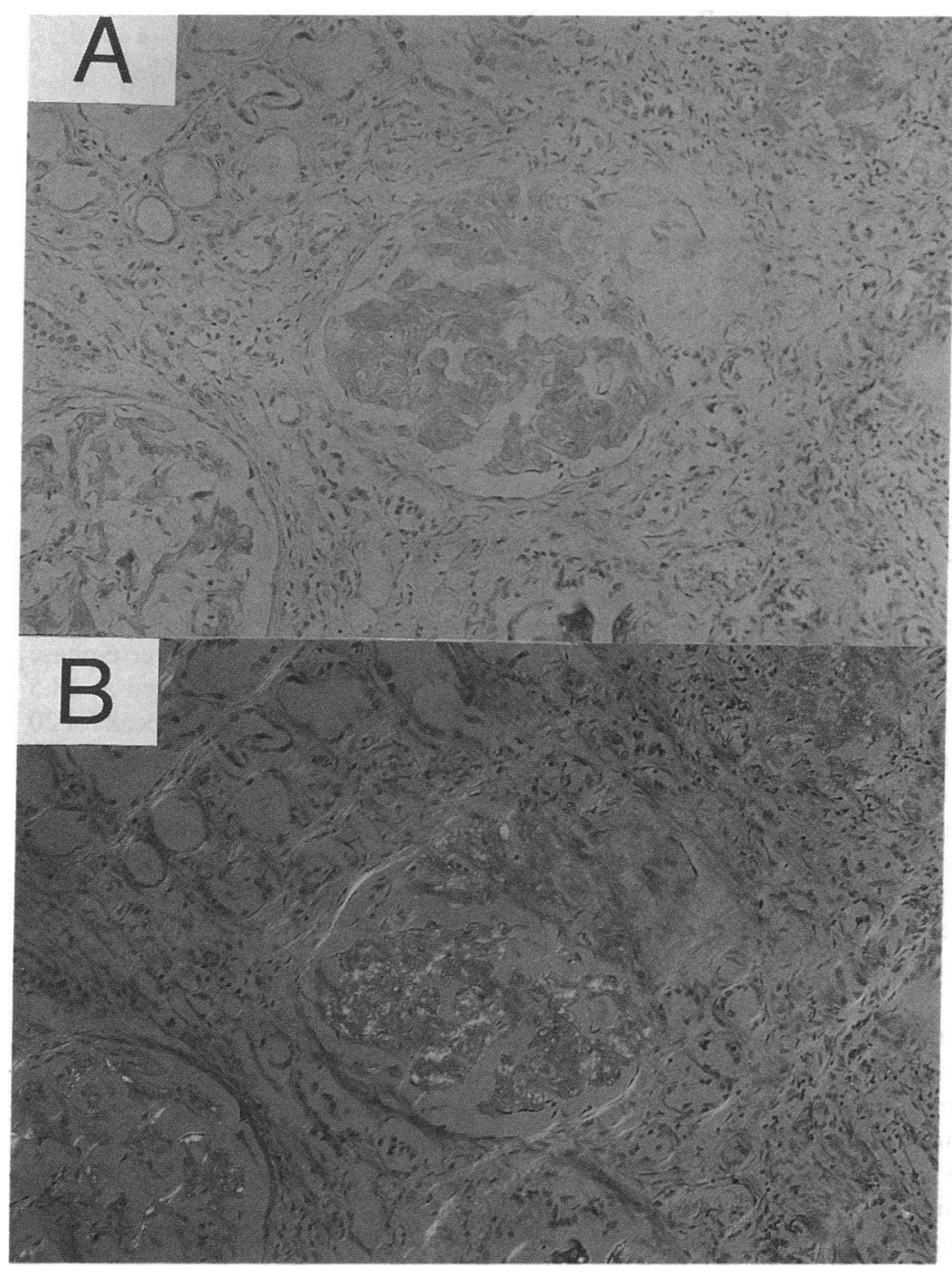

Figure 2. Congo red-stained kidney section of a patient (family D, II-2) showing amyloid deposition in glomerulus $(A)$ in unpolarized light and $(B)$ in polarized light $)$. microconcentrator. $2 \mathrm{ml}$ of Tris-EDTA buffer was added to the sample and the sample was centrifuged at $5,000 \mathrm{~g}$ for $30 \mathrm{~min}$. This was repeated three times. $7 \mu \mathrm{l}$ of the retentate was used for dideoxynucleotide sequencing reaction by Sequenase Version 2.0.

RFLP analysis. DNA samples from 16 members in family D ( 5 affected and 11 individuals at risk) and 14 in family $R$ ( 2 affected and 12 individuals at risk) were examined by the PCR-induced mutation restriction analysis. A Fib4 primer (5'-CAGATTCTGAGCCCCTAGTC-3'), which was arranged to give a recognition site of MaeIII in the mutant gene PCR products, was synthesized and used for amplification with Fib3 primer in the same condition as described above. PCR-amplified DNA fragments were digested with restriction enzyme MaeIII at $55^{\circ} \mathrm{C}$ overnight, electrophoresed through $4 \%$ Nusieve GTG agarose gel, stained with ethidium bromide, and photographed under ultraviolet light.

Plasma fibrinogen studies. Plasma fibrinogen values of two affected members and five unaffected variant fibrinogen carriers were examined functionally by fibrin formation and immunologically by radial immunodiffusion $(20,21)$. Thrombin and reptilase clotting times were performed as described before (22).

Purification of plasma fibrinogen. $36 \mathrm{ml}$ of plasma anticoagulated with trisodium citrate (fibrinogen value; $340 \mathrm{mg} / \mathrm{dl}$ ) was obtained from a family member who had been predicted by DNA analysis to be heterozygous for variant fibrinogen. Plasma was diluted to $100 \mathrm{ml}$ with water and passed through a lysine Sepharose $4 \mathrm{~B}$ column and a gelatin Sepharose $4 \mathrm{~B}$ column equilibrated with $0.1 \mathrm{M}$ phosphate buffer $(\mathrm{pH}$
7.4) $(23,24)$. Ammonium sulfate was then added to the plasma to a final concentration of $25 \%$ and incubated for $1 \mathrm{~h}$ at $4^{\circ} \mathrm{C}(25)$. Precipitated fibrinogen was collected by centrifugation for $30 \mathrm{~min}$ at $8,000 \mathrm{~g}$. This ammonium sulfate precipitation was repeated three times. The precipitated fibrinogen was dialyzed against water and lyophilized. 108 $\mathrm{mg}$ of fibrinogen was obtained. The isolated fibrinogen was found to be highly pure on the basis of sodium dodecylsulfate polyacrylamide gel electrophoresis.

Isolation of residue 518-584 cyanogen bromide fragment of $A \alpha$ chain. Purified plasma fibrinogen $(20 \mathrm{mg}$ ) was treated with $2 \mathrm{ml}$ of $75 \%$ formic acid containing $200 \mathrm{mg}$ of cyanogen bromide for $2 \mathrm{~h}$ at room temperature (26). The volume was reduced to $1 \mathrm{ml}$ with a stream of nitrogen gas, and the digest fractionated on a Sephadex G-50 superfine column $(1.6 \times 86 \mathrm{~cm})$ equilibrated and eluted with $0.25 \%$ trifluoroacetic acid in water. Eluant was monitored by absorbance at $235 \mathrm{~nm}$. The peak eluting after the large void volume peak was pooled and concentrated to $\sim 0.75 \mathrm{ml}$ on a speed vac (Savant Instruments, Inc., Hicksville, NY), and $0.25 \mathrm{ml}$ of $88 \%$ formic acid was added. An aliquot of the sample was fractionated on a $0.46 \times 25-\mathrm{cm}$ Ultrasphere-ODS column (Beckman Instruments, Carlsbad, CA) equilibrated with $0.1 \%$ trifluoroacetic acid, $10 \%$ acetonitrile in water, and eluted with a 10 $50 \%$ acetonitrile gradient over $40 \mathrm{~min}$. Eluant was monitored by absorbance at $215 \mathrm{~nm}$. Peaks were dried in a speed vac.

Peptide sequence determination. Isolated peptides were sequenced on a protein sequencer ( model 473A; Applied Biosystems, Inc., Foster City, CA) using the manufacturer's standard cycles. 


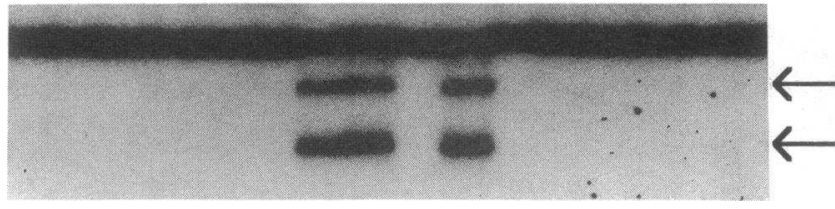

Figure 3. Autoradiography of SSCP gel. Lanes 7, 8, and 10, represent affected individuals in these kindreds, while other lanes represent amyloidosis patients without renal involvement. Abnormally migrating bands are indicated by arrows.

\section{Results}

SSCP analysis revealed an abnormally migrating band in all three affected individuals; two from family $R$, and one from family D (Fig. 3).

Direct DNA sequencing of PCR products of these three patients showed both adenine and thymine at position 4909 of fibrinogen gene (Fig. 4) (18). Thus, they were heterozygous with both a normal GAG (glutamic acid) and a variant GTG (valine) codon at amino acid position 526 of fibrinogen $\mathrm{A} \alpha$ chain (27). The sequence data of these cases were compatible with those of the normal gene except for the transversion.

PCR-RFLP analysis showed that all 7 affected individuals, D II- 1 , and 13 of 22 individuals at risk had the MaeIII recognition site associated with the Val 526 mutation, and therefore, had a digestion band of $76 \mathrm{bp}$, while 9 other individuals at risk showed a normal band of 98 bp (Fig. 5).

The plasma fibrinogen values measured by both functional and immunochemical assays were within the normal range. Thrombin and reptilase clotting times of plasmas from seven members of these kindreds carrying the mutant fibrinogen gene were also normal. To determine if both normal and variant $\mathrm{A} \alpha$ chains were present in plasma fibrinogen, fibrinogen isolated from the plasma of an asymptomatic individual who was positive for the gene mutation was digested with cyanogen bromide and fractionated over a Sephadex G-50 superfine column. The A $\alpha$ chain residue 518-584 cyanogen bromide frag-

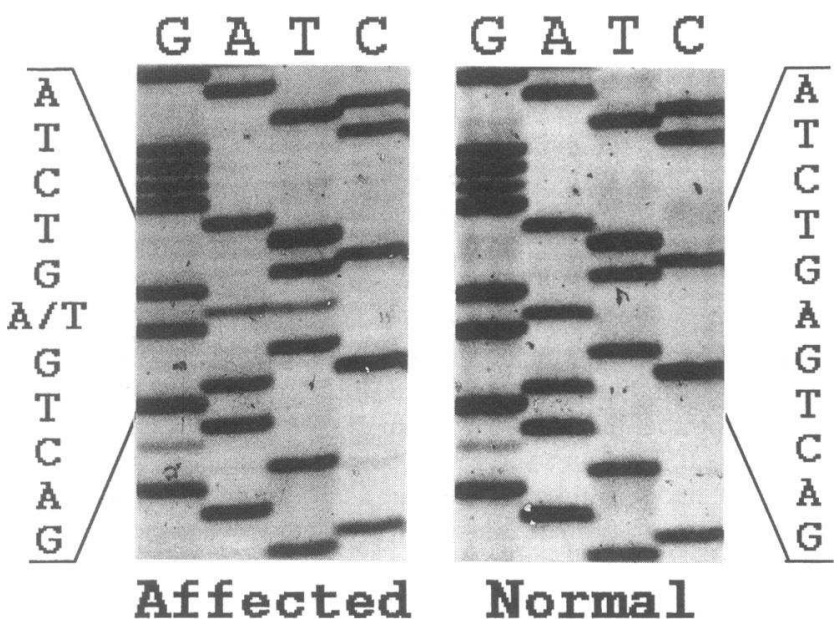

Figure 4. Autoradiography of DNA sequencing gel of an affected individual and a normal control. An affected individual has both adenine and thymine at position 4909 of fibrinogen $\mathrm{A} \alpha$ chain gene indicating heterozygosity for Val 526.

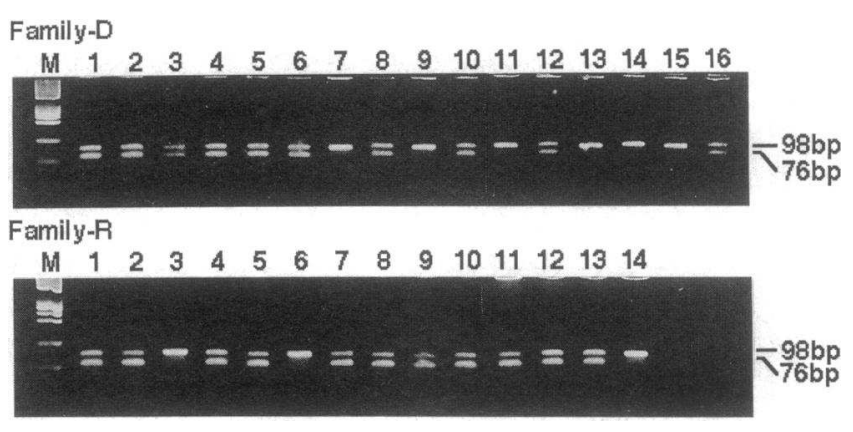

Figure 5. Detection of fibrinogen A $\alpha$ chain Val 526 gene by PCR-induced mutation restriction analysis in family $D$ and family $R$. Lane $M$, DNA size marker ( $\phi \mathrm{X} 174$ DNA-HaelII digest). The figures at the right denote the sizes of the bands in basepairs.

ment eluted in the peak after the large void volume peak containing the large disulfide bridged fragment of fibrinogen. This 518-584 peak was further fractionated by reverse-phase HPLC. Two approximately equal sized peaks eluted at 18.5 and $19.5 \mathrm{~min}$ (Fig. 6). Sequence analysis of the first peak for 20 cycles yielded the normal sequence of residues 518-537 of A $\alpha$ chain: LGEFVSETESRGSESGIFTN. Analysis of the second peak yielded the same sequence except for valine instead of glutamic acid in cycle 9 corresponding to residue 526 in the $\mathrm{A} \alpha$ chain, the substitution predicted from DNA analysis. Thus, both normal and variant $\mathrm{A} \alpha$ chain were present. In addition, equal yields of the two residues were obtained on the sequencer when the unfractionated peak was applied suggesting that equal amounts of normal and variant fibrinogen $\mathrm{A} \alpha$ chains were present in the plasma.

\section{Discussion}

The fibrinogen molecule consists of two identical ensembles each containing an $\mathrm{A} \alpha$-, $\mathrm{B} \beta$-, and $\gamma$-polypeptide chain. The $\mathrm{A} \alpha$ chain is characteristically the largest of the three chains with 610 amino acid residues and a molecular weight of 66,066 . Several fibrinogen $A \alpha$ chain variants have been determined for

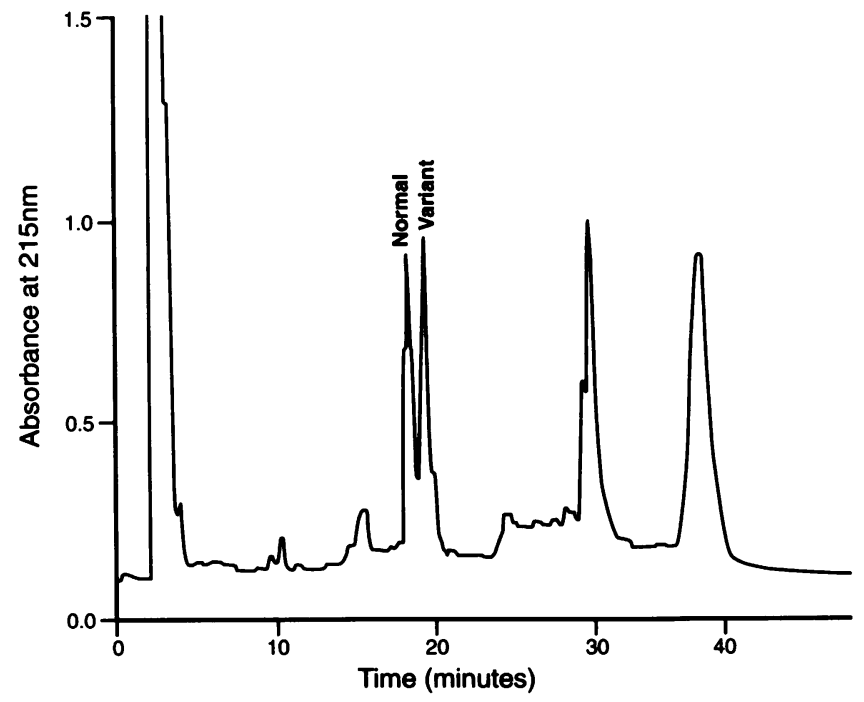

Figure 6. HPLC chromatogram of cyanogen bromide fragments of fibrinogen of a heterozygous mutant gene carrier. 
inherited dysfibrinogenemia (28). All variants have an amino acid substitution in the 19 residues of the amino terminus with exceptions of A $\alpha 461$ AAA (Lys) to TAA (Stop) mutation and Cys 554 mutation $(29,30,31)$.

In a previous study, we isolated a fragment of fibrinogen $\mathrm{A} \alpha$ chain (amino acid residues 500-580) with an amino acid substitution (Fib A $\alpha$ Leu 554) from renal amyloid deposits in an individual of Peruvian descent (14). Although no tissue was available for the examination of amyloid protein in the kindreds described here, the close linkage between the disease and the fibrinogen mutation that has never been reported before in individuals without amyloidosis, strongly suggests the variant fibrinogen to be amyloid precursor protein. In addition, preliminary immunohistological studies using an antiserum raised against the carboxyl-terminal region of fibrinogen revealed positive staining of amyloid deposits in tissue sections of these kindreds. We do not know whether the normal counterpart of the $\mathrm{A} \alpha$ chain is or is not involved in the amyloid deposition in these kindreds. As only variant $\mathrm{A} \alpha$ chain fragments were found in amyloid deposits of the previously characterized Leu 554 patient, it is likely that the amyloid deposits are derived exclusively from variant $\mathrm{A} \alpha$ chain in these kindreds, even though both normal and variant protein were reported to exist in amyloid deposits of transthyretin related amyloidosis patients with a normal/variant chain ratio of $1: 2(32,33)$.

Several proteins ( transthyretin, apolipoprotein $\mathrm{Al}$, gelsolin, and serum amyloid A) are known to be precursor proteins for systemic amyloidosis (1). Though the mechanisms by which these proteins deposit in tissue as amyloid are still unknown, the subunit peptides share two features; they are all derived from plasma proteins and all have molecular size of 8-14 kD.

Important questions in understanding amyloidogenesis with this fibrinogen $\mathrm{A} \alpha$ chain variant include how the mutation alters structure of the protein and how it affects metabolism of the protein. While it is possible that the fibrinogen molecule that contains variant $\mathrm{A} \alpha$ chain degrades more rapidly than the normal molecule, we found that individuals with the variant protein had plasma fibrinogen values in the normal range, and that approximately half of the fibrinogen $\mathrm{A} \alpha$ chain was variant in the individual we examined. This suggests that the amino acid substitution does not interfere with formation of the fibrinogen molecule, and there is no great difference in degradation rate between normal and variant $\mathrm{A} \alpha$ chain. It is likely that the variant $\mathrm{A} \alpha$ chain is contained within the fibrinogen molecule and becomes the amyloid peptide in the process of molecular degradation. The lack of clinical history of bleeding disorders and normal values obtained by clotting studies indicate that the mutation does not significantly affect clotting function in these kindreds.

The most distinctive feature of amyloidosis in these kindreds is that affected individuals have nephropathy as the major manifestation without evidence of neuropathy. Though the mechanism by which amyloid proteins have organ specificity that leads to the variation in clinical features is unknown, the nonneuropathic, nephropathic syndrome seems to be the prominent feature for fibrinogen $\mathrm{A} \alpha$ chain amyloidosis. 10 kindreds, including 2 kindreds described here and the one we studied previously, have been reported to have nonneuropathic, nephropathic amyloidoses. The kindred first described by Ostertag in 1932 and reviewed in 1950 had five affected members in three generations, and death occurred at 18,35 , 36,39 , and $52 \mathrm{yr}$ of age. Renal failure, hypertension, and hepa- tosplenomegaly were reported in this kindred $(13,34)$. Weiss and Page reported four patients in three generations with renal amyloidosis in $1973(35,36)$. These patients had hepatomegaly with amyloid infiltration. Death occurred at the ages of 13 , 43, 47, and 52 yr of age. In 1975, a Canadian kindred of Polish origin with renal amyloidosis was reported by Alexander and Atkins (37). Three siblings developed hypertension and nephrotic syndrome at the ages of 42,52 , and 58 , and died at 49 , 55 , and $60 \mathrm{yr}$ of age. Amyloid deposition was found in kidneys, spleen, and adrenals. In 1981, Mornaghi et al. described 49, 52, and $55 \mathrm{yr}$-old Irish-American siblings with 4-6 yr of clinical history of nephropathy $(38,39)$. These patients also had anemia and hypertension. Six affected members in two generations with renal amyloidosis were described in 1982 by Lanham et al. and shown to be related to a lysozyme gene mutation (His 67) by Pepys et al. $(40,41)$. The onset ages were 23, 33, 33 , and 45 , and death occurred at $33,38,43$, and 49 yr of age. The propositus had keratoconjunctivitis sicca. Libbey and Talbert described an American case of Scandinavian descent who had a history of hypertension and progressive renal dysfunction since the age of $25 \mathrm{yr}$ and died of hepatic failure at the age of 43 (42). Autopsy showed splenomegaly and slight hepatomegaly. The patient's mother died of renal amyloidosis at the age of $58 \mathrm{yr}$. Amyloid protein of this patient was revealed to be apolipoprotein $\mathrm{Al}$ Arg 26 by Jones et al., which had been originally reported by Nichols et al. in a family with familial amyloid polyneuropathy $(4,43)$. An English kindred with renal amyloidosis and skin petechiae was described by Zalin et al. and Fitch et al. in $1991(44,45)$. Six patients in two generations had petechiae and three of them developed amyloidosis at 24,27 , and $50 \mathrm{yr}$ of age. Hepatosplenomegaly and nodular small bowel mesentery were reported. This kindred was also found to have a variant lysozyme (Thr 56) (41). Soutar et al. described an English kindred in which eight patients in four generations were affected with renal amyloidosis (46). Severe splenomegaly was noted. Apolipoprotein Al mutation Arg 60 was associated with amyloidosis in this kindred.

The patients studied in this paper developed renal dysfunction in their forties to sixties. It is notable that these two kindreds who share the same mutation have similar onset ages. It is close to the onset ages of the kindreds described by Weiss and Page and by Mornaghi et al., but later than those of other kindreds including the one reported by Benson et al. (14), where amyloidosis was associated with a variant fibrinogen (Leu 554). While our patients had hypertension, they did not have hepatosplenomegaly, and this appears to be characteristic for these kindreds.

While both kindreds studied here are of Irish descent, no relation could be established from family or medical records. Even so, it is more likely that they have a common ancestry in Ireland than to have the mutation occur independently. Further study in Ireland may reveal other kindreds with HRA and serve to establish a genealogic link.

\section{Acknowledgments}

We would like to thank Dr. Nils Bang and Cathy Harms for helpful discussion and measuring plasma fibrinogen concentration and activities, Dr. Agnes Henschen for help in isolation and analysis of fibrinogen, and Carmen J. Reynolds for excellent technical assistance. Also we thank Dr. Roger Wiggins and Dr. William Schmidt for their generous help in evaluation of family $R$. 
This work was supported by the Department of Veterans Affairs, the National Institutes of Health, the Alzheimer Association, and the Marion E. Jacobson Fund.

\section{References}

1. Benson, M. D. 1991. Inherited amyloidosis. J. Med. Genet. 28:73-78.

2. Dwulet, F. E., and M. D. Benson. 1983. Polymorphism of human plasma thyroxine binding prealbumin. Biochem. Biophys. Res. Commun. 114:657-662.

3. Tawara, S., M. Nakazato, K. Kangawa, H. Matsuo, and S. Araki. 1983. Identification of amyloid prealbumin variant in familial amyloidotic polyneuropathy (Japanese type). Biochem. Biophys. Res. Commun. 116:880-888.

4. Nichols, W. C., R. E. Gregg, B. Brewer, Jr., and M. D. Benson. 1990. A mutation in apolipoprotein A-1 in the lowa type of familial amyloidotic polyneuropathy. Genomics. 8:318-323.

5. Maury, C. P. J., J. Kere, R. Tolvanen, and A. de la Chapelle. 1990. Finnish hereditary amyloidosis caused by a single nucleotide substitution in the gelsolin gene. FEBS (Fed. Eur. Biochem. Soc.) Lett. 276:75-77.

6. Levy, E., M. Haltia, I. Fernandez-Madrid, O. Koivunen, J. Ghiso, F. Prelli, and B. Frangione. 1990. Mutation in gelsolin gene in Finnish hereditary amyloidosis. J. Exp. Med. 172:1865-1867.

7. de la Chapelle, A., R. Tolvanen, G. Boysen, J. Santavy, L. Bleeker-Wagemakeers, C. P. J. Maury, and J. Kere. 1992. Gelsolin-derived familial amyloidosis caused by asparagine or tyrosine substitution for aspartic acid at residue 187 . Nature Genet. 2:157-160.

8. Goate, A., M. C. Chartier-Harlin, M. Mullan, J. Brown, F. Crawford, L. Fidani, L. Giuffra, A. Haynes, N. Irving, L. James, et al. 1991. Segregation of a missense mutation in the amyloid precursor protein gene with familial Alzheimer's disease. Nature (Lond.). 349:704-706.

9. Murrell, J., M. Farlow, B. Ghetti, and M. D. Benson. 1991. A mutation in the amyloid precursor protein associated with hereditary Alzheimer's disease. Science (Wash. DC). 254:97-99.

10. Chartier-Harlin, M. C., F. Crawford, H. Houlden, A. Warren, D. Hughes, L. Fidani, A. Goate, M. Rossor, P. Roques, J. Hardy, and M. Mullan. 1991. Early-onset Alzheimer's disease caused by mutations at codon 717 of the $\beta$-amyloid precursor protein gene. Nature (Lond.). 353:844-846.

11. Levy, E., M. D. Carman, I. J. Fernandez-Madrid, M. D. Power, I. Lieberburg, S. G. van Duinen, G. T. A. M. Bots, W. Luyendijk, and B. Frangione. 1990. Mutation of Alzheimer's disease amyloid gene in hereditary cerebral hemorrhage, Dutch type. Science (Wash. DC). 248:1124-1126.

12. Ghiso, J., B. Pons-Estel, and B. Frangione. 1986. Hereditary cerebral amyloid angiopathy: the amyloid fibrils contain a protein which is a variant of cystatin $\mathrm{C}$, an inhibitor of lysosomal cysteine proteases. Biochem. Biophys. Res. Commun. 136:548-554.

13. Ostertag, B. 1932. Demonstration einer eigenartigen familiaren "Paramyloidose." Zentralbl. Allg. Pathol. 56:253-254.

14. Benson, M. D., J. Liepnieks, T. Uemichi, G. Wheeler, and R. Correa. 1993. Hereditary renal amyloidosis associated with a mutant fibrinogen $\alpha$-chain. Nature Genet. 3:252-255.

15. Madisen, L., D. I. Hoar, C. D. Holroyd, M. Crisp, and M. E. Hodes. 1987. DNA banking: the effects of storage of blood and isolated DNA on the integrity of DNA. Am. J. Med. Genet. 27:379-390.

16. Orita, M., Y. Suzuki, T. Sekiya, and K. Hayashi. 1989. Rapid and sensitive detection of point mutations and DNA polymorphisms using the polymerase chain reaction. Genomics. 5:874-879.

17. Uemichi, T., J. R. Murrell, S. Zeldenrust, and M. D. Benson. 1992. A new mutant transthyretin (Arg 10) associated with familial amyloid polyneuropathy. J. Med. Genet. 29:888-891.

18. Chung, D. W., J. E. Harris, and E. W. Davie. 1991. Nucleotide sequences of the three genes coding for human fibrinogen. Adv. Exp. Med. Biol. 281:39-48.

19. Nichols, W. C., J. J. Liepnieks, V. A. McKusick, and M. D. Benson. 1989. Direct sequencing of the gene for Maryland/German familial amyloidotic polyneuropathy type II and genotyping by allele-specific enzymatic amplification. Genomics. 5:535-540.

20. Clauss, A. 1957. Gerinnungsphysiologische Schnellmethode zur Bestimmung des Fibrinogens. Acta. Haematol. 17:237-246.

21. Mancini, G., A. O. Carbonara, and J. Heremans. 1965. Immunochemical quantitation of antigens by single radial immunodiffusion. Immunochemistry. 2:235-254.

22. Caen, J., M. J. Larrieu, and M. Samama. 1975. L'Hémostase, Méthode d'Exploration et de Diagnostic Pratique. L'Expansion Scientifique Française, Paris.

23. Deutsch, D. G., and E. T. Mertz. 1970. Plasminogen: purification from human plasma by affinity chromatography. Science (Wash. DC). 170:10951096.

24. Engvall, E., and E. Ruoslahti. 1977. Binding of soluble form of fibroblast surface protein, fibronectin, to collagen. Int. J. Cancer. 20:1-5.

25. Kazal, L. A., G. F. Grannis, and L. M. Tocantins. 1964. Preparation of fibrinogen by glycine precipitation (Method of Kazal, Miller, Amsel, and Tocantins). In Blood Coagulation, Hemorrhage and Thrombosis. L. Tocantins and L. Kazal, editors. Grune \& Stratton Inc., New York. pp. 232-239.

26. Liepnieks, J. J., F. E. Dwulet, and M. D. Benson. 1990. Amino acid sequence of a kappa I primary (AL) amyloid protein (AND). Molec. Immunol. 27:481-485.

27. Doolittle, R. F., K. W. K. Watt, B. A. Cottrell, D. D. Strong, and M. Riley. 1979. The amino acid sequence of the $\alpha$-chain of human fibrinogen. Nature (Lond.). 280:464-468.

28. Matsuda, M., N. Yoshida, S. Terukina, K. Yamazumi, and H. Maekawa. 1990. Molecular abnormalities of fibrinogen-the present status of structure elucidation. In Fibrinogen 4: Current Basic and Clinical Aspects. M. Matsuda, S. Iwanaga, A. Takeda, and A. Henschen, editors. Excerpta Medica, Amsterdam. pp. 139-152.

29. Koopman, J., F. Haverkate, J. Grimbergen, R. Egbring, and S. T. Lord. 1992. Fibrinogen Marburg: a homozygous case of dysfibrinogenemia, lacking amino acids A $\alpha$ 461-610. (Lys 461 AAA-Stop TAA). Blood. 80:1972-1979.

30. Siebenlist, K. R., M. W. Mosesson, J. P. DiOrio, J. Soria, and J. P. Caen. 1993. The polymerization of fibrinogen Dusart (A $\alpha 554$ Arg-Cys) after removal of carboxy terminal regions of the A $\alpha$-chains. Blood Coagul. \& Fibrinolysis. 4:61-65.

31. Koopman, J., F. Haverkate, J. Grimbergen, S. T. Lord, M. W. Mosesson, J. P. DiOrio, K. S. Siebenlist, C. Legrand, J. Soria, C. Soria, and J. P. Caen. 1993. Molecular basis for fibrinogen Dusart (A $\alpha 554$ Arg-Cys) and its association with abnormal fibrin polymerization and thrombophilia. J. Clin. Invest. 91:16371643

32. Dwulet, F. E., and M. D. Benson. 1984. Primary structure of an amyloid prealbumin and its plasma precursor in a heredofamilial polyneuropathy of Swedish origin. Proc. Natl. Acad. Sci. USA. 81:694-698.

33. Dwulet, F. E., and M. D. Benson. 1986. Characterization of a transthyretin (prealbumin) variant associated with familial amyloidotic polyneuropathy type II (Indiana/Swiss). J. Clin. Invest. 78:880-886.

34. Ostertag, B. 1950. Familiäre Amyloid-Erkrankung. Z. Menschl. Vererbungs-Konstitutionsl. 30:105-115.

35. Weiss, S. W., and D. L. Page. 1973. Amyloid nephropathy of Ostertag with special reference to renal glomerular giant cells. Am. J. Pathol. 72:447-460.

36. Weiss, S. W., and D. L. Page. 1974. Amyloid nephropathy of Ostertag: report of a kindred. Birth Defects. 4:67-68.

37. Alexander, F., and E. L. Atkins. 1975. Familial renal amyloidosis, case reports, literature review and classification. Am. J. Med. 59:121-128.

38. Mornaghi, R., P. Rubinstein, and E. C. Franklin. 1981. Studies on the pathogenesis of a familial form of renal amyloidosis. Trans. Assoc. Am. Phys. 94:211-216.

39. Mornaghi, R., P. Rubinstein, and E. C. Franklin. 1982. Familial renal amyloidosis: case reports and genetic studies. Am. J. Med. 73:609-614.

40. Lanham, J. G., M. L. Meltzer, F. C. De Beer, G. R. V. Hughes, and M. B. Pepys. 1982. Familial amyloidosis of Ostertag. Q. J. Med. 201:25-32.

41. Pepys, M. B., P. N. Hawkins, D. R. Booth, D. M. Vigushin, G. A. Tennent, A. K. Soutar, N. Totty, O. Nguyen, C. C. F. Blake, C. J. Terry, et al. 1993. Human lysozyme gene mutations cause hereditary systemic amyloidosis. Nature (Lond.). 362:553-557.

42. Libbey, C. A., and M. L. Talbert. 1987. Clinicopathological conference. $N$. Engl. J. Med. 317:1520-1531.

43. Jones, L. A., J. A. Harding, A. S. Cohen, and M. Skinner. 1991. New USA family has apolipoprotein $\mathrm{Al}$ (Arg26) variant. In Amyloid and Amyloidosis 1990/VIth International Symposium on Amyloidosis. J. B. Natvig, Ø. Førre, G. Husby, et al., editors. Kluwer Academic Publishers Group, Dordrecht, The Netherlands. pp. 385-387.

44. Zalin, A. M., S. Jones, N. J. S. Fitch, and D. B. Ramsden. 1991. Familial nephropathic non-neuropathic amyloidosis: clinical features, immunohistochemistry and chemistry. Q.J. Med. 81:945-956.

45. Fitch, N. J. S., A. M. Zalin, and D. B. Ramsden. 1991. Familial amyloidosis without transthyretin (TTR) involvement: an unusual presentation. In Amyloid and Amyloidosis 1990/VIth International Symposium on Amyloidosis. J. B. Natvig, Ø. Førre, G. Husby, et al., editors. Kluwer Academic Publishers Group, Dordrecht, The Netherlands. pp. 702-705.

46. Soutar, A. K., P. N. Hawkins, D. M. Vigushin, G. A. Tennent, S. E. Booth, T. Hutton, O. Nguyen, N. F. Totty, T. G. Feest, J. J. Hsuan, and M. B. Pepys. 1992. Apolipoprotein Al mutation Arg-60 causes autosomal dominant amyloidosis. Proc. Natl. Acad. Sci. USA. 89:7389-7393. 